\title{
Ten years of a hantavirus disease emergency in the Federal District, Brazil
}

\author{
Roberto de Melo Dusi ${ }^{[1],[2],}$ Angelika Bredt ${ }^{[2]}$, Daniel Roberto Coradi de Freitas ${ }^{[3]}$, \\ Maria Isabel Rao Bofill[2], José Alexandre Menezes da Silva ${ }^{[4]}$, \\ Stefan Vilges de Oliveira ${ }^{[1]}$ and Pedro Luiz Tauil[ ${ }^{[1]}$
}

[1]. Programa de Pós-Graduação em Medicina Tropical, Universidade de Brasília, Brasília, Distrito Federal, Brasil. [2]. Subsecretaria de Vigilância em Saúde, Secretaria de Estado da Saúde do Distrito Federal, Brasília, Distrito Federal, Brasil. [3]. Centro de Gerenciamento de Informações para Emergências em Vigilância Sanitária, Agência Nacional de Vigilância Sanitária, Brasília, Distrito Federal, Brasil. [4]. Secretaria Executiva de Vigilância em Saúde, Secretaria Estadual de Saúde de Pernambuco, Recife, Pernambuco, Brasil.

\begin{abstract}
Introduction: Hantavirus diseases are emerging human diseases caused by Hantavirus spp. of the Bunnyaviridae family. Hantavirus pulmonary syndrome (HPS) has been detected in the Federal District (DF) of Brazil since 2004. Among the 27 Brazilian Federal Units, DF has the highest fatality rate. More than 10 years have already passed since then, with confirmation of cases caused by the Araraquara and Paranoa species. The reservoir is Necromys lasiurus. Methods: Local surveillance data of the confirmed cases were analyzed, including age, sex, month and year of occurrence, clinical symptoms, syndromes and outcomes, and probable transmission place (PTP). The cases were mainly confirmed by IgM detection with a capture enzyme immunoassay. The cases were classified as autochthonous if PTPs were in the DF area. Results: From 2004 to 2013, in the DF, 126 cases of hantavirus were confirmed, and the cumulative incidence was 5.0 per 100,000 inhabitants. The occurrence of cases was predominantly from April to August. At least $75 \%$ of the cases were autochthonous. Acute respiratory failure was reported in $47.5 \%$ of cases, and the fatality rate was $40 \%$. Conclusions: In the DF, the cumulative incidence of HPS was one of the highest worldwide. A seasonal pattern of hantavirus disease in the dry season is clear. There was a high frequency of severe clinical signals and symptoms as well as a high fatality rate. For the near future, visitors and inhabitants of DF rural areas, particularly male adults, should receive continuous education about hantavirus transmission and prevention.
\end{abstract}

Keywords: Hantavirus. Infectious disease. Epidemiological surveillance.

\section{INTRODUCTION}

Hantavirus diseases are emerging infectious diseases caused by the genus Hantavirus, of the family Bunyaviridae ${ }^{(1)}$. First described in South Korea in the 1950s, as Korean hemorrhagic fever, the etiologic agent was only isolated in $1977^{(2)}$. Rodents are the main reservoirs of hantavirus, and transmission occurs through contact with blood or excreta of infected rodents or by inhaling aerosols containing the virus ${ }^{(3)}$.

The geographic distribution of the two distinct major clinical syndromes between the different continents is very distinct. Hantavirus pulmonary syndrome (HPS) occurs in the Americas $^{(4)}{ }^{(5)}$, while hemorrhagic fever with renal syndrome (HFRS) occurs in Europe and Asia ${ }^{(2)(3)(6)}$, with occasional reports of cross occurrence ${ }^{(7)}$.

Corresponding author: Dr. Roberto de Melo Dusi.

e-mail: robertodusi@hotmail.com I robertodusi@aluno.unb.br

Received 1 August 2015

Accepted 11 December 2015
In Brazil, the first confirmed cases were reported in 1993, and 1,906 cases were reported nationwide until 2014; of these, 448 (25.6\%) cases were reported in the Brazilian Midwest region. Cases have been reported in all five regions of the country and distributed in $14(51.9 \%)$ of the 27 Brazilian Federal Units $(B F U s)^{(8)(9)}$. In 2004, cases were first reported in the Federal District (DF), as an outbreak ${ }^{(10)}$, and during recent years, the DF has had the highest fatality rates among the BFUs ${ }^{(11)}$.

At least three different monophiletic clades of hantavirus have been detected in South America and are also found throughout Brazil. However, in the DF, only the Andes clade, which includes the Araraquara and Paranoa genotypes, has been found so $\operatorname{far}^{(12)(13)}$. There are different clinical and epidemiological patterns related with the diversity of the etiological agent ${ }^{(14)}$. Some hantavirus species are linked with HFRS and others with HPS, each with specific environmental scenarios and climate patterns. In the rural areas of the DF, the reservoir for hantavirus transmission is the wild rodent Necromys lasiurus ${ }^{(15)(16)(17)}$.

The DF has a population of over 2.8 million inhabitants and includes the Brazilian capital City of Brasília ${ }^{(18)}$. Limited by the parallel $15^{\circ} 30^{\prime} \mathrm{S}$ and $16^{\circ} 03^{\prime} \mathrm{S}$, with altitude ranging from 750 
to 1,344 meters above sea level, the DF has an area of nearly $5,800 \mathrm{~km}^{2}$. The climate is tropical, with a dry winter, monthly mean temperatures of $13-22^{\circ} \mathrm{C}$, and environmental relative humidity of $11-75 \%$. The vegetation is typical of the savanna ${ }^{(19)}$. There is a high proportion of agricultural activities in rural areas. During the 10-year period between the emergence of hantavirus disease in the DF in 2004(10) (20) and 2013, cases have been confirmed every year, and there has been territorial expansion. This study describes the main epidemiological aspects of hantavirus cases in the DF during these 10 years of detection.

\section{METHODS}

This epidemiological, descriptive, observational study used data collected by the DF surveillance system teams in 2004-2013. The data sources were records from the National Notifiable Diseases System (SINAN) and reports from visits to households and sites of activity of cases by the environmental health surveillance team.

For confirmed cases, the following variables were analyzed: age, sex, month and year of occurrence, clinical symptoms, syndromes and outcomes, and probable transmission place (PTP). All cases were confirmed using laboratory tests, mainly with a capture enzyme-linked immunosorbent assay (ELISA) designed to detect the anti-hantavirus class $\mathrm{M}(\operatorname{IgM})$ antibody ${ }^{(21)}$. The suspected cases in the DF were tested using ELISA with the recombinant nucleocapsid protein of Andes and Araraquara, which are native South American species ${ }^{(22)(23)}$. For a few cases, sera were not available; therefore, immunohistochemistry for hantavirus was used. Laboratory tests were performed at a reference institution for the Brazilian National Surveillance System ${ }^{(24)}$.

The PTPs for hantavirus disease are geographic points that are considered places of exposure reported by confirmed cases or their proxies, verified by the specialized environmental health surveillance, and classified as receptive for transmission. The PTPs were marked with geographical positioning devices, and the coordinates were recorded in the Universal Transverse Mercator ${ }^{(25)}$. The cases were classified as autochthonous if PTPs were in the $\mathrm{DF}$ area, regardless of the place of residence. The cases treated in Brasília, with one or more PTPs outside the DF, were considered allochthonous. Notified inpatient cases with acute disease who did not survive were classified as death. Notified cases with an address in the DF territory were classified as inhabitants.

Absolute and relative frequencies were calculated, including simple proportions and incidence rates by year and as averages for each month during the study period. The results are graphically depicted. The study was approved by the Ethics Committee for Research with Humans Beings of DF Health Secretariat.

\section{RESULTS}

During the first 10 years of detection, 126 cases of hantavirus disease were confirmed, resulting in a cumulative incidence rate of 5.0 cases per 100,000 inhabitants.
There were no cases aged $<10$ years. The incidence for those aged 20-49 years was almost double that of the other age groups. The incidence for men was also almost double that of women, except for persons aged $<20$ years (Table 1).

The curves of the cases by year for all inpatient cases, regardless of residence, and residents of the DF were both bimodal, with similar shapes and considerably more cases in 2004 (Figure 1). In the months from April to August, the mean numbers of cases were at least two times higher than those in the other months (Figure 2).

The PTP was classified by the environmental health investigation for $104(82.5 \%)$ cases: $85(81.7 \%)$ in the DF and/or another BFU and 78 (75\%) only in the DF (Figure 3). The other BFUs included the rural areas of 11 municipalities of State of Goiás and two municipalities of the State of Minas Gerais, all of which are very close to, and even border, the DF.

Fever, dyspnea, and myalgia were recorded for $94.2 \%$, $87.5 \%$, and $85.8 \%$ of cases, respectively. Acute respiratory failure (47.5\%), hemorrhagic signs (25.8\%), circulatory shock $(15 \%)$, and renal failure (10\%) were also reported (Figure 4). The hantavirus disease fatality rate in the DF during the study period was $40 \%$.

TABLE 1 - Absolute numbers and incidence rates per 100,000 inhabitants of hantavirus disease confirmed in the Federal District, Brazil, 2004-2013.

\begin{tabular}{|c|c|c|c|c|c|c|}
\hline \multirow{2}{*}{$\begin{array}{l}\text { Age group } \\
\text { (years old) }\end{array}$} & \multicolumn{2}{|c|}{ Female } & \multicolumn{2}{|c|}{ Male } & \multicolumn{2}{|c|}{ Total } \\
\hline & (n) & (rate) & (n) & (rate) & (n) & (rate) \\
\hline$<10$ & - & - & - & - & - & - \\
\hline $10-19$ & 9 & 4.0 & 7 & 3.2 & 16 & 3.6 \\
\hline $20-49$ & 31 & 4.6 & 64 & 10.6 & 95 & 7.4 \\
\hline$\geq 50$ & 6 & 2.8 & 9 & 5.4 & 15 & 3.9 \\
\hline Total & 46 & 3.5 & 80 & 6.7 & 126 & 5.0 \\
\hline
\end{tabular}

\section{DISCUSSION}

The cumulative incidence rate of HPS in the DF from 2004 to 2013 was 5.0 cases per 100,000 inhabitants. In Brazil, there were 1,486 cases of HPS reported from 2001 to 2011, for a cumulative incidence rate of $0.080^{(26)}$. Comparatively, from 1995 to 2008 in Argentina, there were 750 HPS cases ${ }^{(27)}$, for a cumulative incidence rate of 1.955 per 100,000 inhabitants. In Chile, which is the most endemic country in the Americas, the mean incidence rate by year was 0.290 per 100,000 inhabitants, and in the USA it was 0.009 per 100,000 inhabitants ${ }^{(5)}$. During the 20 years since the 1993 Four Corners outbreak in the USA, 


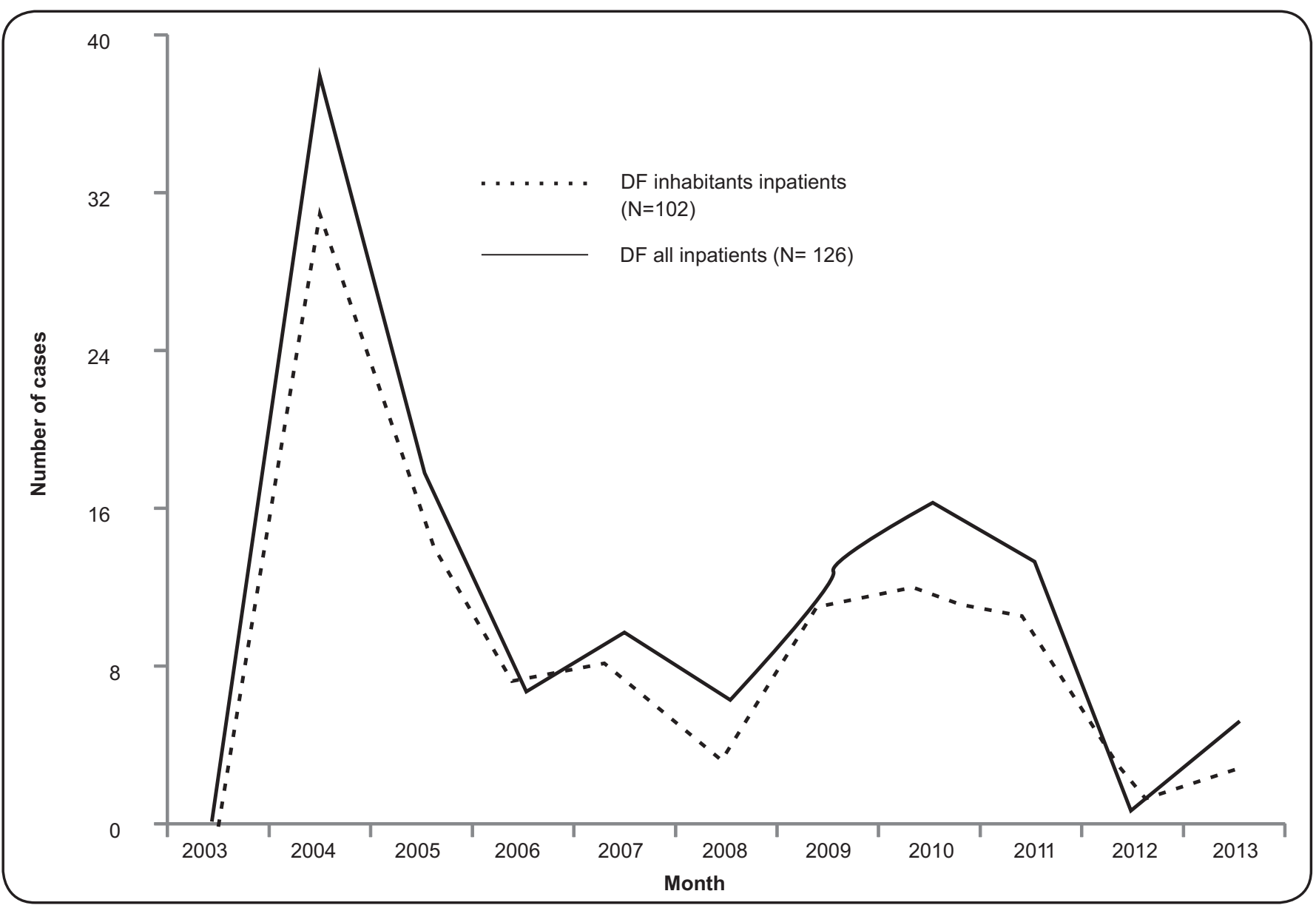

FIGURE 1 - Hantavirus disease by year and inpatients status, in the Federal District (DF) of Brazil, 2004-2013.

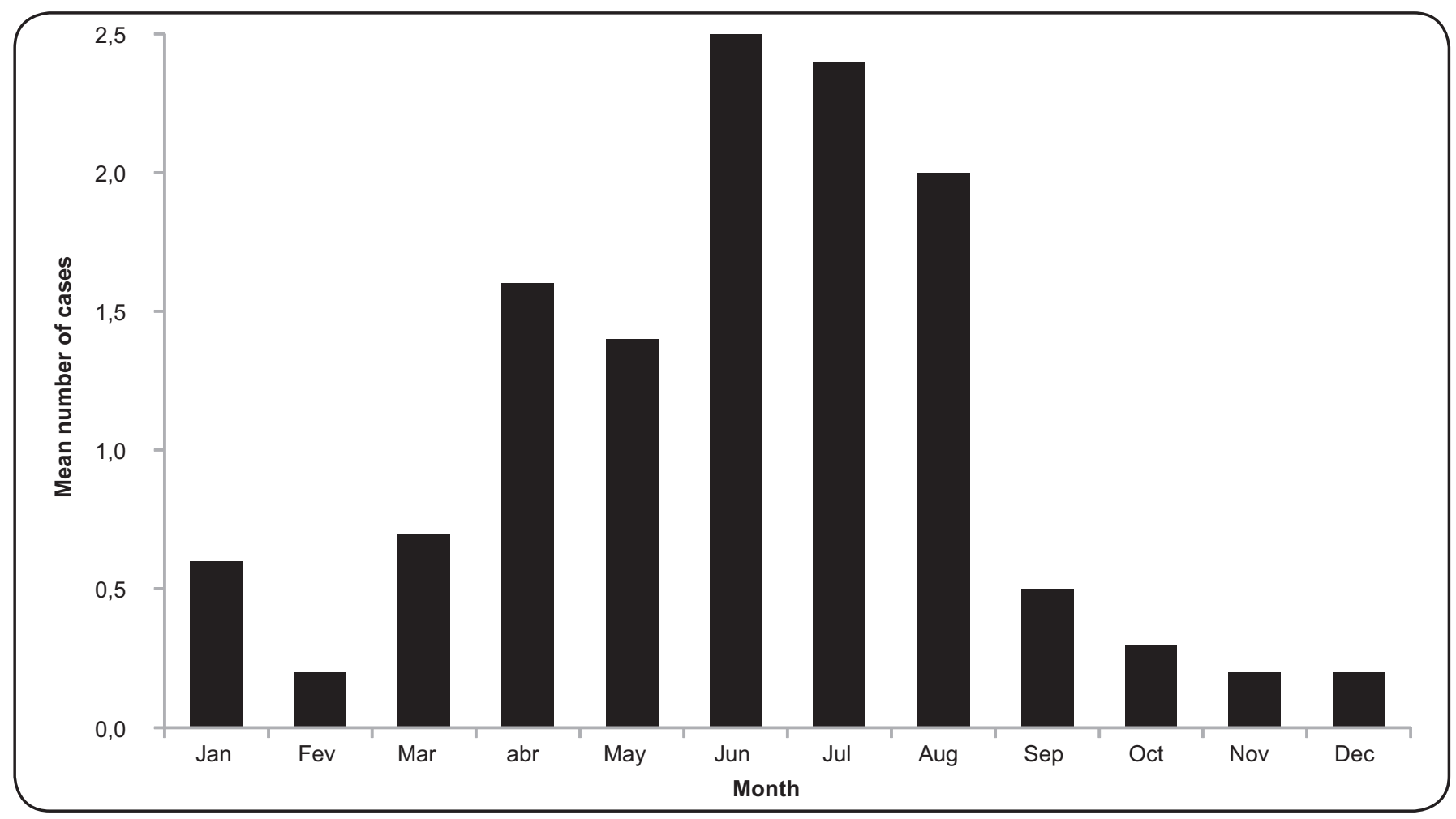

FIGURE 2 - Mean monthly curve for confirmed cases of hantavirus disease, Federal District (DF), Brazil, 2004-2013. 


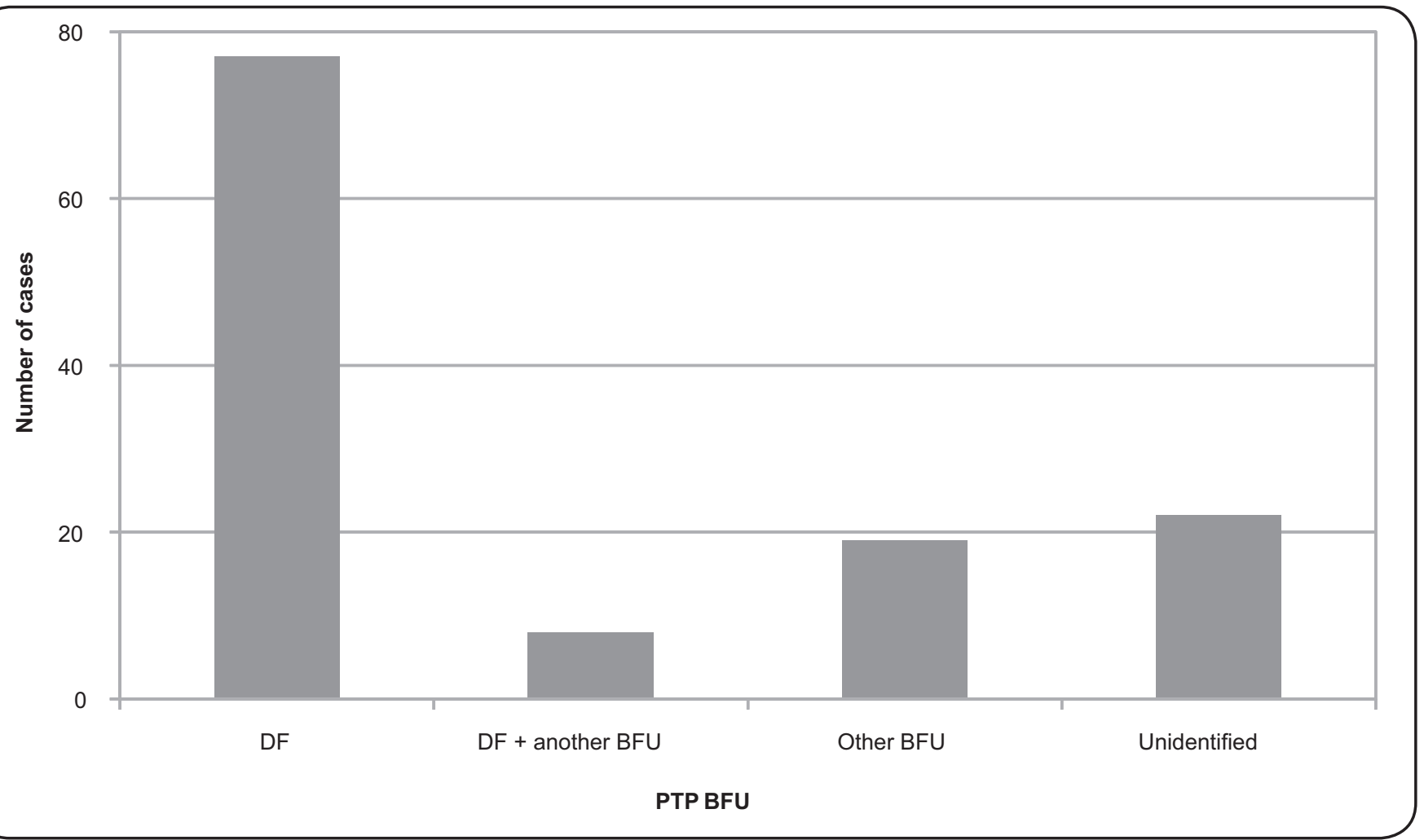

FIGURE 3 - Probable transmission places (PTP) of confirmed cases of hantavirus disease in the Federal District (DF) and other Brazilian Federal Units (BFU), 2004-2013.

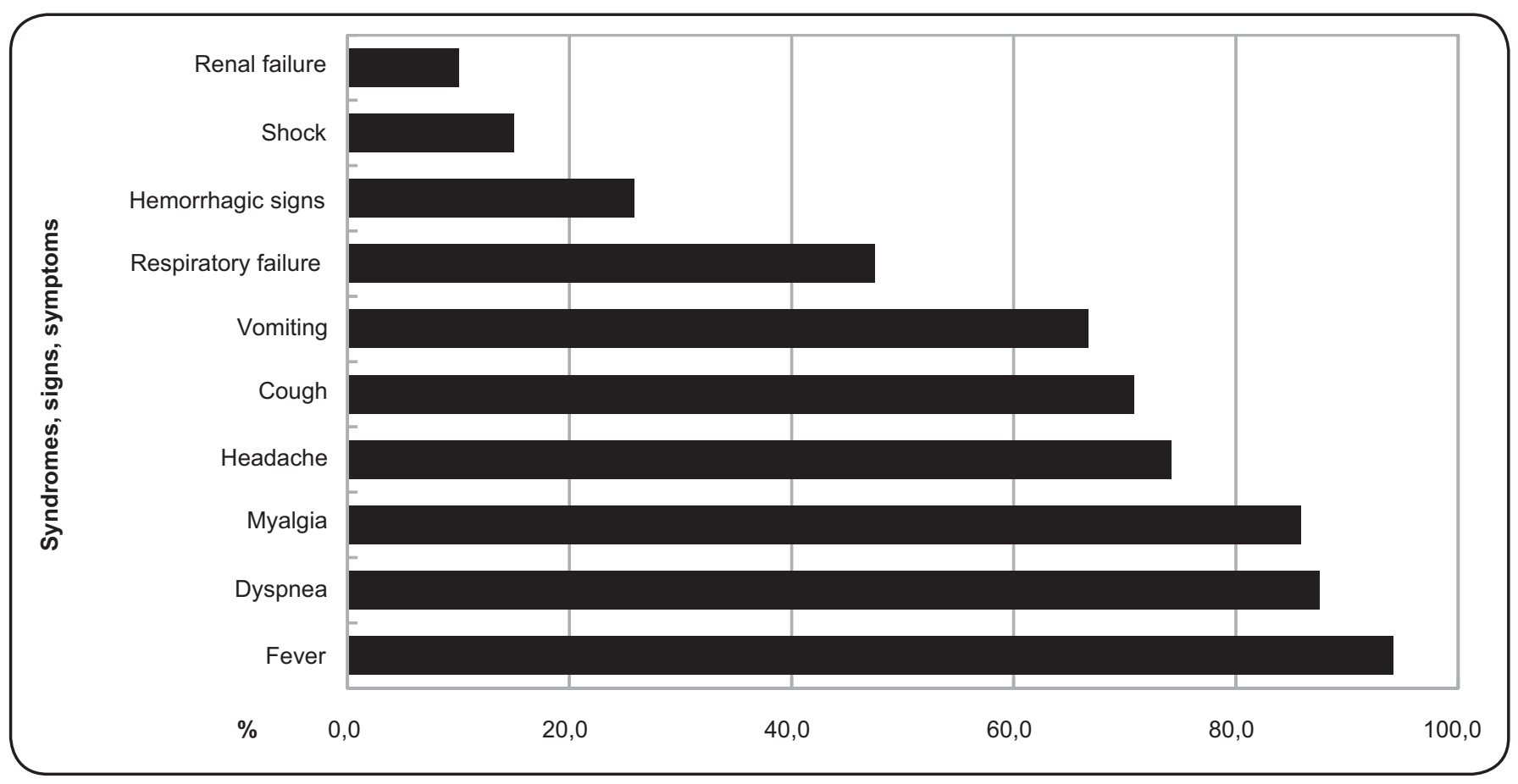

FIGURE 4 - Most frequent symptoms and relevant syndromes detected in confirmed hantavirus disease cases, Federal District (DF), Brazil, 2004-2013. 
there were 624 HPS confirmed cases, scattered throughout 34 states $^{(12)}$.

In 2014, the incidence rate in Brazil was 0.092 per 100,000 inhabitants, and the incidence in the affected BFUs ranged from 0.028 to 1.343 per 100,000 inhabitants. According to the Brazilian Ministry of Health, the DF had the highest incidences among the 11 affected BFUs in 2004 and 2005, with 1.343 and 0.686 per 100,000 inhabitants, respectively ${ }^{(28)}{ }^{(29)}$. By 2009 , $5.6 \%$ of all of the hantavirus disease cases reported nationwide in Brazil were in the $\mathrm{DF}^{(24)}$.

Regarding age, the incidence was much higher in those aged 20-49 years in the present study; the same age group accounted for $67.7 \%$ of confirmed HPS cases in 2004 and $>70 \%$ of confirmed HPS cases in 2005 in Brazil ${ }^{(28)(29)}$. In the DF, HPS was not confirmed in persons younger than 10 years old. In Brazil, there were only 19 (1.6\%) confirmed cases of HPS in persons younger than 10 years old from 1993 to 2009.

Eighty (63.5\%) HPS cases in the DF were men, and the number of male cases of HPS was twice as high as the number of female cases in those aged $\geq 20$ years. In Brazil, $80 \%$ of the HPS cases were men ${ }^{(24)}$.

The curves for number of cases by year for DF inhabitants and all persons treated in the DF peaked in 2004 and 2010 for both groups, mainly in 2004, indicating that the small portion of cases that originated from outside the DF had the same context of transmission as the inhabitants. The number of cases in the DF in 2004 was equivalent to that registered in Brazil from 1993 to $2000^{(24)}$. Because there are no reports of hantavirus before 2004, the detection of HPS cases in the DF started in 2004. A retrospective study in the US using laboratory tests of tissue samples from fatal cases with unclear causes detected $>30$ cases in the 15 years before the Four Corners outbreak ${ }^{(30)}$. In Europe, hantavirus disease has demonstrated a particular cyclical temporal pattern; in boreal regions, the number of cases increases every three years ${ }^{(31)}$. The bimodal pattern demonstrated in the DF might indicate that the occurrence is also cyclical.

There were reports of HPS in the DF in every month of the year from 2004 to 2013. However, the monthly means for the months from April to August were at least two times higher than those in other months, indicating a seasonal pattern. The DF climate is characterized by two seasons: rainy and dry ${ }^{(19)}$. The peak incidence of HPS was reported during the dry and cold season, which was also observed in a presumably descriptive study in Uberlândia, Minas Gerais that included only 23 cases during an 8-year period ${ }^{(32)}$ and in the State of São Paulo, as reported using a sophisticated scientific method ${ }^{(33)}$. In contrast, a seasonal pattern was not found in another study of Brazilian geographical regions (BGRs) ${ }^{(26)}$. However, BGRs have different biomes, landscapes, and climates, such as the Midwest, where hantavirus occurs in two very different climatic contexts.

In this study, the HPS fatality rate in the DF was similar to the Brazilian fatality rate of $42 \%$ from 1993 to $2009^{(24)}$. Comparatively, the fatality rates in the USA, Chile, and Argentina were $35 \%{ }^{(34)}, 30 \%$, and $25.8 \%{ }^{(27)}$, respectively. The differences in the fatality rates by country might be explained by the higher virulence of some hantavirus species ${ }^{(35)}$ or the clinical spectrum of hantavirus disease, which ranges from a mild clinical course to cardio-respiratory failure and death ${ }^{(31)}$. In some severe cases, the patients also had an underlying illness, such as chronic pulmonary disease ${ }^{(4)}$. Whereas $90 \%$ of HPS deaths occur within 48 hours from symptom onset ${ }^{(5)}$, the differences in the quality of care among hospitals should also be considered.

Fever, dyspnea, and myalgia are included in the case definition $^{(24)}$ and were reported in a high percentage of the cases in the DF. The severe signs and symptoms, such as acute respiratory failure, hemorrhagic signs, and circulatory shock, also affected many cases. The severe pattern of signs and symptoms in the DF, including respiratory symptoms, indicates that HPS is primarily present. All 12 cases with renal failure also had respiratory failure or dyspnea. Renal failure appeared in approximately $20 \%$ of the cases registered in Brazil from 1993 to $2006^{(8)}$. Therefore, renal failure in cases in the DF might be a late complication, similar to pre-renal acute failure ${ }^{(5)(31)}$. However, HFRS cases confirmed in the USA ${ }^{(12)}$ may also suggest the presence of this form of disease in other countries in America.

Regarding the limitations of this study, the Brazilian national databases have been in a constant adaptation process to the technological resources, creating instability in the information system. The spread of epidemiological information in different institutions, with no concatenate records, accentuate this instability. Calculations of the incidence rates in the DF used all cases treated in DF hospitals, regardless of BFU address. Autochthonous cases represented at least $75 \%$ among those whose PTP was identified. Also, the frequent changes in DF territorial occupation create some difficulty for epidemiological analysis ${ }^{(20)}$.

From 2004 to 2013, HPS in the DF presented with great severity, even higher than other regions of America, despite the low incidence, when compared with all other health problems. The high fatality rate and predominance among men and young adults in the DF were similar to what occurs in Brazil. Nevertheless, the fatality rate was higher than in other countries.

There was a bimodal distribution in the DF, suggesting that hantavirus disease should have a cyclical temporal pattern in this area. Seasonality was also observed, and the cases originated from DF and nearby, although the PTPs were predominantly in the DF.

A human hantavirus infection seroprevalence basedpopulation study in the DF would provide some answers regarding the epidemiological pattern of this disease in this area. For the near future, visitors and inhabitants of rural areas in the DF, particularly male adults, should receive continuous education about hantavirus transmission and prevention. Medical assistance should be sought immediately after onset of symptoms in a suspected case of hantavirus disease.

\section{ACKNOWLEDGMENTS}

The authors appreciate the contributions of the physicians and all officials of the Brazilian Surveillance teams to the data collection and laboratory tests for cases of suspected hantavirus disease in the DF. We acknowledge the Universidade de Brasilia and Subsecretaria de Vigilância em Saúde, Secretaria de Estado 
da Saúde do Distrito Federal, Brasília for technical support. The authors are also grateful to Renata Garcia Dusi and Rubia Garcia Dusi for review of the manuscript.

\section{CONFLICT OF INTEREST}

The authors declare that there is no conflict of interest.

\section{REFERENCES}

1. Schmaljohn CS, Dalrymple JM. Analysis of hantaan virus RNA: Evidence for a new genus of bunyaviridae. Virology 1983; 131:482-491.

2. Lee HW, Lee PW, Johnson KM. Isolation of the etiologic agent of Korean hemorrhagic fever. J Infect Dis 1978; 137:298-308.

3. Yates TL, Mills JN, Parmenter CA, Ksiazek TG, Parmenter RR, Castle JRV, et al. The Ecology and Evolutionary History of an Emergent Disease: Hantavirus Pulmonary Syndrome Evidence from two El Niño episodes in the American Southwest suggests that El Niño-driven precipitation, the initial catalyst of a trophic cascade that results in a delayed density-dependent rodent response, is sufficient to predict heightened risk for human contraction of hantavirus pulmonary syndrome. Bioscience 2002; 52:989-998.

4. Duchin JS, Koster FT, Peters C, Simpson GL, Tempest B, Zaki SR, et al. Hantavirus pulmonary syndrome: a clinical description of 17 patients with a newly recognized disease. N Engl J Med 1994; 330:949-955.

5. Manigold T, Vial P. Human hantavirus infections: epidemiology, clinical features, pathogenesis and immunology. Swiss Med Wkly 2014; 144:w13937.

6. Sheedy JA, Froeb HF, Batson HA, Conley CC, Murphy JP, Hunter RB, et al. The clinical course of epidemic hemorrhagic fever. Am J Med 1954; 16:619-628.

7. Rasmuson J, Andersson C, Norrman E, Haney M, Evander M, Ahlm C. Time to revise the paradigm of hantavirus syndromes? Hantavirus pulmonary syndrome caused by European hantavirus. Eur J Clin Microbiol Infect Dis 2011; 30:685-690.

8. Ministério da Saúde. Secretaria de Vigilância em Saúde. Casos confirmados de hantavirose no Brasil, Grandes Regiões e Unidades Federadas. 1993 a 2015 [Internet]. 2015 [Cited 2015 July 10]. Available at: http://portalsaude.saude.gov.br/images/pdf/2015/ junho/01/CASOS-CONF-HANTAVIROSE-01-06-2015.pdf.

9. Elkhoury M da R, da Silva Mendes W, Waldman EA, Dias JP, Carmo EH, da Costa Vasconcelos PF. Hantavirus pulmonary syndrome: prognostic factors for death in reported cases in Brazil. Trans R Soc Trop Med Hyg 2012; 106:298-302.

10. Ministério da Saúde (MS). Secretaria de Vigilância em Saúde. Surto da síndrome cardiopulmonar por hantavírus no Dsitrito Federal e Goiás - Maio a Setembro de 2004. Boletim Eletrônico Epidemiológico. $1^{\circ}$ ed. Brasília: MS; 2004; p. 1-5.

11. de Oliveira SV, Fonseca LX, Barros PMR, Pereira SVC, de Caldas EP. Análise do perfil epidemiológico da hantavirose no Brasil no período de 2007 a 2012. Rev Patol Trop 2014; 43:131-142.

12. Firth C, Tokarz R, Simith DB, Nunes MR, Bhat M, Rosa ES, et al. Diversity and distribution of hantaviruses in South America. J Virol 2012; 86:13756-13766.

13. Melo-Silva CR, Maranhão AQ, Nagasse-Sugahara TK, Bisordi I, Suzuki A, Brigido MM. Characterization of hantaviruses circulating in Central Brazil. Infect Genet Evol 2009; 9:241-247.
14. Knust B, Rollin PE. Twenty-year summary of surveillance for human hantavirus infections, United States. Emerg Infect Dis Virus 2013; 19:1934-1937.

15. de Oliveira SV, Escobar LE, Peterson AT, Gurgel-Gonçalves R. Potential geographic distribution of hantavirus reservoirs in Brazil. PloS One 2013; 8:e85137.

16. Suzuki A, Bisordi I, Levis S, Garcia J, Pereira LE, Souza RP, et al. Identifying rodent hantavirus reservoirs, Brazil. Emerg Infect Dis 2004; 10:2127-2134.

17. Willemann MCA, de Oliveira SV. Risk factors associated with hantavirosis fatality: a regional analysis from a case-control study in Brazil. Rev Soc Bras Med Trop 2014; 47:47-51.

18. Instituto Brasileiro de Geografia e Estatística (IBGE). Censo demográfico 2010. Dados por unidade federada [Internet]. 2011 [Cited 2012 August]. Available at: http://www.ibge.gov.br/ estadosat/perfil.php?sigla $=\mathrm{df}$.

19. Gonçalves TD, Roig HL, Campos JEG. Sistema de informação geográfica como ferramenta de apoio à outorga dos recursos hídricos subterrâneos no Distrito Federal. Rev Bras Geociências 2009; 39:169-180.

20. Bredt A, de Oliveira C, Massunaga PN, Santos MA, Bofill MIR, de Almeida R. A hantavirose e o uso e ocupação do solo no Distrito Federal. Belém: Instituto Evandro Chagas. 2004. p. 149.

21. Niklasson B, Kjelsson T. Detection of nephropathia epidemica (Puumala virus)-specific immunoglobulin $\mathrm{M}$ by enzyme-linked immunosorbent assay. J Clin Microbiol 1988; 26:1519-1523.

22. Padula PJ, Rossi CM, Valle MOD, Martínez PV, Colavecchia SB, Edelstein A, et al. Development and evaluation of a solid-phase enzyme immunoassay based on Andes hantavirus recombinant nucleoprotein. J Med Microbiol 2000; 49:149-155.

23. Figueiredo LTM, Moreli ML, Borges AA, de Figueiredo GG, Badra SJ, Bisordi I, et al. Evaluation of an enzyme-linked immunosorbent sssay based on Araraquara Virus Recombinant Nucleocapsid Protein. Am J Trop Med Hyg 2009; 81:273-276.

24. Ministério da Saúde (MS). Secretaria de Vigilância em Saúde. Manual de Vigilância, Prevenção e Controle das Hantaviroses [Internet]. Brasil: MS; 2013. 92 p. Available at: http://pesquisa. bvsalud.org/bvsms/resource/pt/oai-bvs-ms-ms-36803.

25. Bredt A, Massunaga PNT, Maia ES, dos Santos DE, Silva JAM. Análise ambiental dos locais prováveis de infecção para hantavirose no DF. Brasília: Instituto Evandro Chagas; 2004. p. 148.

26. Pinto Jr V, de Sousa A, de Lemos E. Regional variations and time trends of hantavirus pulmonary syndrome in Brazil. Epidemiol Infect 2014; 142:2166-2171.

27. Martinez VP, Bellomo CM, Cacace ML, Suárez P, Bogni L, Padula PJ. Hantavirus pulmonary syndrome in Argentina, 1995-2008. Emerg Infect Dis 2010; 16:1853.

28. Ministério da Saúde (MS). Secretaria de Vigilância em Saúde. Epidemiologia da hantavirose e da síndrome cardiopulmonar por hantavírus no Brasil no ano de 2005. Boletim Eletrônico Epidemiológico. Brasília: MS; 2006. p. 1-5.

29. Ministério da Saúde (MS). Secretaria de Vigilância em Saúde. Aspectos epidemiológicos da infecção e da patogenicidade por hantavirus no Brasil. Boletim Eletrônico Epidemiológico. $3^{\circ}$ ed Brasília: MS; 2005. p. 1-5.

30. Zaki SR, Khan AS, Goodman RA, Armstrong LR, Greer PW, Coffield LM, et al. Retrospective diagnosis of hantavirus pulmonary syndrome, 1978-1993: implications for emerging infectious diseases. Arch Pathol Lab Med 1996; 120:134-139. 
31. Vaheri A, Henttonen H, Voutilainen L, Mustonen J, Sironen T, Vapalahti O. Hantavirus infections in Europe and their impact on public health. Rev Med Virol 2013; 23:35-49.

32. Limongi JE, Costa FC, Paula MBC, Pinto RMC, Oliveira MLA, Pajuaba Neto AA, et al. Síndrome cardiopulmonar por hantavírus no Triângulo Mineiro e Alto Paranaíba, Minas Gerais, 1998-2005: aspectos clínico-epidemiológicos de 23 casos. Rev Soc Bras Med Trop 2007; 40:295-299.

33. Donalisio MR, Vasconcelos $\mathrm{CH}$, Pereira LE, Ávila AMH, Katz G. Aspectos climáticos em áreas de transmissão de hantavirose no Estado de São Paulo, Brasil. Cad Saúde Pública 2008; 24:11411150.

34. MacNeil A, Ksiazek TG, Rollin PE. Hantavirus pulmonary syndrome, United States, 1993-2009. Emerg Infect Dis 2011; 17:1195.

35. Jonsson CB, Figueiredo LTM, Vapalahti O. A global perspective on hantavirus ecology, epidemiology, and disease. Clin Microbiol Rev 2010; 23:412-441. 